227.

${ }^{201} \mathrm{~T} 1$ 負荷心筋シンチグラムにおける一過性左室拡大の定量的評洒

Quantitative evaluation of transient dilation of the left ventricle on exercise Tl sintigraphy

京都府立医科大学付属病院 放射線科

○水田 正芳

中田 克哉 武部 義行

田畑 則之 岡本 邦蜼、山口 義和

（目的） ${ }^{201} \mathrm{~T} 1$ 負荷心筋シンチグラムで負荷直後像の左室内腔が3-4時間後に比し視覚的に拡大する例が存在する。そこで、 今回この抎大所見を定量的に評僻する力法を考案し、その有用性を検討した。

(方法）負荷時およで3時間後のSPECT短軸像において、中心から10度每に放射状值線上の各最大カウントの点で䎴まれる 面皘を求め、負荷時面積/3時間後面積(EX/RD)を一過性左室拡大の指標とした。

(結果) 本指標は、容易に算出可能であり、虚血の診断の一助となると思わ扎、二指病変例の $40 \%$ 三指病変例の $80 \%$ 一過 性拡大が見られた。

228.

等距離变換法によ:る心筋壁厚の2 次元表示

Tow-Dimensional Representation of the Myocardial wall Thickness by Isodistance Transformation Method 愛媛大学医学部附属病院 放射線部 $\bigcirc$ 中田 茂 渡部 真二 川上 㝘昭

【目的】心筇S P E C Tにより得られた 3 次元画像を 1 枚の 2 次元画像に変換すると、心筋壁厚の情報が失われる欠点があった。 今回、等距離变換法を用いて 2 次元画像に変換する際に、心筋壁厚も測定し、心筋壁厚の2 次元画像を作成したのて報告する。

【方法】第46回総会学術大会において報告した等距離变換法を用いて、心筋内壁から外壁までのカウントを求める。

得られたカーブを心筋壁中央より外壁側に问かって、2個の指数関数で近似し、その半値幅を心筋壁厚とした。

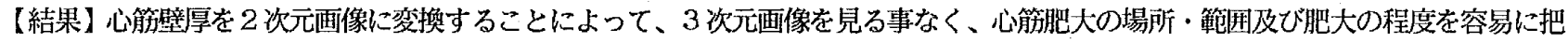
握する事妸能になった。

229.

心筋SPECTにおけるsmoothing filterと心筋厚の評価

Evaluation of SPECT smoothing filters for the measurement of myocardial thickness

滋賀医大付属病院 ○高橋雅文 大西英雄 濱津尚就 增田一孝 大阪工業大学 兽我部秀一

（目的）心筋SPECTによる心筋厚の評価は最適前処理フィルターを用いて画像の再構成を行なわない場合、画像 復元に誤差が生じ心筋厚の正礁な評価は困難である。我々は最適前処理フイルターとエッヂを保ったスムージ ング法の組み合わせにより画像を改善し心筋厚の評価を試みた。

(方法) 胸部ファントームに心筋厚の異なる $(1.5,1.0,0.5 \mathrm{~cm})$ ファントームを入れ従来法で再構成したものと、 最適前処理フィルターで画像を再構成した画像に種々のエッヂを保ったスムージングと 9 点スムージング等を 組み合わせた中から最適なフィルターを選び出しその心筋厚を比較した。臨床においては99mTc-MIBIのGATED SPECTにこのフィルターを組み合わせて心筋厚を評価した。

(結果) $99 \mathrm{mTc}$ のファントーム実驗において前者は 5 m前後、エッデを保ったフィルターの組み合わせは約 $2 \mathrm{~mm}$ 前 後の過大評価となり充分改善された。またGATED SPECT像より正確な心筋像を得ることができた。

\title{
230. 発表取消し
}

